\title{
Case Comments
}

\section{The Sorcerer's Apprentice:}

\section{Sandoval, Chevron, and Agency Power}

\section{To Define Private Rights of Action}

\author{
Peters v. Jenney, 327 F.3d 307 (4th Cir. 2003); Jackson v. Birmingham \\ Board of Education, 309 F.3d 1333 (11 th Cir. 2002), petition for cert. filed, \\ 71 U.S.L.W. 3736 (U.S. May 13, 2003) (No. 02-1672).
}

Private individuals have long played a key role in enforcing federal rights.' Yet in a series of recent decisions, the Supreme Court has limited the ability of individuals to enforce federal rights through private suits. ${ }^{2}$ In Alexander v. Sandoval, for example, the Court held that there was no private right of action to enforce disparate impact regulations promulgated under Title VI of the Civil Rights Act of $1964 .{ }^{3}$ It is unclear, however, whether that decision precluded private rights of action to enforce other regulations promulgated under Title VI and comparable civil rights statutes.

1. See Carlos Manuel Vázquez, Eleventh Amendment Schizophrenia, 75 NOTRE DAME L. REV. 859, 873 (2000) ("[T]hroughout our history, the constitutional rights of individuals and minorities have primarily been enforced through private suits."); Rebecca E. Zietlow, Federalism's Paradox: The Spending Power and Waiver of Sovereign Immunity, 37 WAKE FOREST L. REV. 141, 214-15 (2002) ("[E]nforcement [of federal law] by private individuals is particularly important in the area of civil rights.... One reason for that reliance is that the federal government simply lacks the resources to prosecute numerous violations of civil rights."); cf. Erwin Chemerinsky, Protecting the Spending Power, 4 CHAP. L. REV. 89, 104 (2001) (arguing that Congress needs to be able to "condition federal funds on a state's waiver of its sovereign immunity" to "ensur[e] accountability"). This role is made necessary by limited governmental resources. See, e.g., Zietlow, supra, at $208 \mathrm{n} .409$ (discussing studies noting the decrease in federal enforcement of civil rights over the last decade).

2. See, e.g., Gonzaga Univ. v. Doe, 536 U.S. 273 (2002); Barnes v. Gorman, 536 U.S. 181 (2002); see also William E. Thro \& Derek P. Langhauser, Emerging Limitations on Federal Authority, 176 EDUC. L. REP. 505, 509-12 (2003) (discussing limitations on private enforcement of federal statutes and regulations).

3. 532 U.S. $275(2001)$. 
Even more significantly, Sandoval left unclear whether, and to what extent, federal agencies can shape private rights of action.

While Sandoval's broad language implied that agencies can play only a limited role in creating private rights of action, its holding still allows substantial room for agencies to define those rights. Indeed, a recent split between the Fourth and the Eleventh Circuits illustrates that Sandoval does not necessarily preclude agencies from playing such a role. Although the Eleventh Circuit, in Jackson v. Birmingham Board of Education, ${ }^{4}$ held that there was no private right of action to enforce anti-retaliation regulations promulgated under Title IX of the Education Amendments of 1972, the Fourth Circuit, in Peters $v$. Jenney, ${ }^{5}$ held that a private individual can sue under Title VI of the Civil Rights Act of 1964 to enforce the anti-retaliation regulations promulgated under that statute. ${ }^{6}$ The critical distinction between the two courts' analyses was the significance each attached to the requirement of deference to agency regulations established by Chevron U.S.A. Inc. v. National Resources Defense Council, Inc. ${ }^{7}$

This Comment argues that the Fourth Circuit was correct to incorporate Chevron into its analysis, and that its decision suggests a role for agencies in creating implied private rights of action that is much greater than the one articulated in Sandoval. While Sandoval may prevent agencies from creating private rights of action by themselves, they can achieve much the same effect by expansively interpreting the statutory rights of action created by Congress. With careful regulatory and statutory drafting, agencies and Congress can - and should - capitalize on the Chevron deference shown by the Fourth Circuit in Peters v. Jenney.

Title VI of the Civil Rights Act of 1964 prohibits racial discrimination in all programs that receive federal funding. ${ }^{8}$ Section 601 of Title VI provides that no person shall "on the ground of race, color, or national origin, be excluded from participation in, be denied the benefits of, or be

4. 309 F.3d 1333 (11th Cir. 2002), petition for cert. filed, 71 U.S.L.W. 3736 (U.S. May 13, 2003) (No. 02-1672).

5. 327 F.3d 307 (4th Cir. 2003).

6. Title IX and Title VI are in pari materia. Therefore the circuits are functionally in conflict despite the fact that the cases deal with different statutes. See id. at 326 (Widener, J., dissenting).

7. 467 U.S. 837 (1984) (holding that courts should defer to reasonable agency interpretations of the statutes they enforce where congressional intent is ambiguous). A federal district court has identified this circuit split, see Chandamuri v. Georgetown Univ., 274 F. Supp. 2d 71, 81-83 (D.D.C. 2003), but that court did not discuss the differing importance the Fourth and Eleventh Circuits attached to Chevron. Instead, Chandamuri relied on statutory interpretation to decide that the Fourth Circuit was correct to recognize a private right of action for retaliation. See infra note 33 .

8. See 42 U.S.C. $\S 2000 \mathrm{~d}(2000)$. 
subjected to discrimination under any program or activity receiving Federal financial assistance." Section 602 authorizes federal agencies that administer programs covered by section 601 to "effectuate the provisions of [section 601] ... by issuing rules, regulations, or orders of general applicability." $"$ Title IX of the Education Amendments of 1972, which prohibits gender discrimination in educational programs receiving federal funding, was patterned after Title VI and has a similar structure. ${ }^{11}$ Section 901 prohibits discrimination, ${ }^{12}$ while section 902 empowers agencies to "effectuate the provisions of" section $901 .^{13}$

In Alexander $v$. Sandoval, a private individual sued to enforce a regulation promulgated by the Department of Justice under Title VI. ${ }^{14}$ This regulation prohibited funding recipients from "utiliz[ing] criteria or methods of administration which have the effect of subjecting individuals to discrimination because of their race, color, or national origin." 15 The Court held that there was no implied private right of action to enforce such a regulation. Although the Court had earlier recognized an implied private right of action to enforce section $601,{ }^{16}$ it held that Sandoval's suit could not be brought pursuant to that right, as the Court had previously construed section 601 to permit the disparate impact practices that the regulations prohibited. ${ }^{17}$ Therefore, the plaintiff could bring a private action only if one existed under section 602 or the regulation itself. The Court searched the structure and text of section 602 for clear evidence of congressional intent to create a private right of action, but found none, relying in large part on the lack of "rights-creating language" in the text of section $602 .{ }^{18}$

The Court then turned to the DOJ regulation. Although the regulation contained the "rights-creating language" that, in statutory text, would have suggested the existence of an implied private right of action, the Court quickly dismissed the possibility that the regulation itself could create such a right: "Language in a regulation may invoke a private right of action that Congress through statutory text created, but it may not create a right that Congress has not.... Agencies may play the sorcerer's apprentice but not the sorcerer himself." "19 Thus, Sandoval seemed to restrict significantly the

\section{Id.}

10. Id. $\S 2000 \mathrm{~d}-1$.

11. See Cannon v. Univ. of Chi., 441 U.S. 677, 694 (1979) ("Title IX was patterned after Title VI of the Civil Rights Act of 1964.").

12. See 20 U.S.C. $\S 1681(\mathrm{a})$.

13. Id. $\S 1682$.

14. 532 U.S. $275(2001)$.

15. 28 C.F.R. $\$ 42.104(b)(2)$ (2003). A similar regulation was promulgated by the Department of Transportation. See 49 C.F.R. $\$ 21.5(\mathrm{~b})(2)$.

16. See Cannon, 441 U.S. 677.

17. See Regents of the Univ. of Cal. v. Bakke, 438 U.S. 265, 287 (1978) (plurality opinion) (holding that section 601 prohibits only intentional discrimination).

18. See Sandoval, 532 U.S. at 288 (internal quotation marks omitted).

19. Id. at 291 (citing Touche Ross \& Co. v. Redington, 442 U.S. 560,577 n. 18 (1979)). 
role that federal agencies could play in creating private rights of action. Yet as the split between the Fourth and Eleventh Circuits suggests, appearances can be deceiving.

Cheryl Peters was hired by the Virginia Beach School Board to serve as Director of Gifted Education and Magnet Programs. In this role, she worked to promote minority enrollment in the school district's gifted and talented program. When the Board decided not to renew Peters's probationary contract, she claimed that it was because of her work to end discrimination, and filed suit. ${ }^{20}$ Her claim was based in part on a Department of Education Title VI regulation, which provides that "[n]o recipient or other person shall intimidate, threaten, coerce, or discriminate against any individual for the purpose of interfering with any right or privilege secured by section 601 of the Act." ${ }^{31}$ The district court granted the Board's motion for summary judgment, and the Fourth Circuit reversed. ${ }^{22}$

Roderick Jackson coached the girls' basketball team at Ensley High School. He complained to his supervisors that the girls' team was not receiving the same support as the boys' team, and the school subsequently relieved him of his coaching duties. ${ }^{23}$ The Department of Education had incorporated by reference its Title VI regulations to enforce Title IX, ${ }^{24}$ and Jackson sued the school board, alleging that it had retaliated against him in violation of Title IX and the implementing regulations. The district court dismissed his complaint, and the Eleventh Circuit affirmed. ${ }^{25}$

In determining whether a private right of action exists to enforce the anti-retaliation regulations promulgated under Title IX, the Eleventh Circuit attempted to follow Sandoval by searching for clear congressional intent to create a private right of action. The court first examined the text of section 901 and found no suggestion of "any congressional concern with retaliation." ${ }^{26}$ As Sandoval had held with respect to section 602, Jackson held that section 902 was "concerned exclusively with the power of federal agencies to regulate recipients of federal funds.... [It] plainly does not disclose any congressional intent to imply a private right of action of any kind...."27 Finally, the Eleventh Circuit dismissed the idea that the

20. Peters v. Jenney, 327 F.3d 307, 313 (4th Cir. 2003).

21. 34 C.F.R. $\S 100.7$ (e) (2003).

22. See Peters, 327 F.3d at 310-11.

23. Jackson v. Birmingham Bd. of Educ., 309 F.3d 1333, 1335 (1 Ith Cir. 2002), petition for cert. filed, 71 U.S.L.W. 3736 (U.S. May 13, 2003) (No. 02-1672).

24. 34 C.F.R. $\$ 106.71$.

25. Jackson, 309 F.3d at 1335.

26. Id. at 1344 .

27. Id. at 1345 (citation omitted). 
regulations themselves could create a private right of action: "Quite simply, if Congress did not enact a statute creating a private cause of action, we cannot find its intent to do so in this regulation." 28

The Eleventh Circuit's conclusion is unsurprising given Sandoval's repeated declarations that Congress must clearly state its intent to create a private right of action. Yet the Eleventh Circuit failed to recognize that Sandoval's rejection of a private right of action in the absence of clear congressional intent was limited to section $602 .^{29}$ It did not apply to section 601 , for which the Court had previously recognized a private right of action. More problematically, the Jackson court ignored altogether the role that Chevron deference should play in determining the proper scope of a private right of action. As the Fourth Circuit noted, Sandoval acknowledged that "regulations applying $\S 601$ 's ban on intentional discrimination are covered by the cause of action to enforce that section." ${ }^{30}$ Yet the Eleventh Circuit did not even consider the possibility that the anti-retaliation regulations might be applying section 901 's ban on intentional discrimination.

In Sandoval, prior case law had already determined that section 601 prohibited only intentional discrimination. The Court thus could not consider the disparate impact regulations at issue to be an authoritative interpretation of section 601 or an application of that section's ban on intentional discrimination. ${ }^{31}$ But there were no such precedents constraining agency interpretations of the intentional discrimination prohibition with respect to retaliation. Indeed, the Fourth Circuit relied upon this distinction

28. Id. at 1346 .

29. See Alexander v. Sandoval, 532 U.S. 275, 288-89 (2001).

30. Id. at 284, cited in Peters v. Jenney, 327 F.3d 307, 315 (4th Cir. 2003). The distinction between regulations "applying $\S 601$ 's ban on intentional discrimination" and regulations promulgated under section 602 to "effectuate the provisions of $\S 601$ " is an important one given that a private right of action exists only for the former. The difference, however, is not always clear. Presumably, regulations "applying"-i.e., interpreting-section 601 define and explain the meaning of its provisions, while regulations promulgated to effectuate its provisions under section 602 are new programs or prohibitions that cannot be said to fall within the confines of section 601 's language but achieve objectives broadly compatible with its goals. Thus, regulations defining which entities are recipients of federal financial assistance might fall under section 601 , because they explicate the meaning of that section. But regulations requiring employers to include their nondiscrimination policy in advertisements for employees might fall under section 602 , because while not directly applying section 601 , they help agencies achieve the broad goals of that section. Agencies themselves need to be sensitive to this distinction. By casting their regulations as interpretations of statutory language, they can maximize the likelihood that courts will defer to the regulations. See infra notes $40-42$ and accompanying text.

31. See Sandoval, 532 U.S. at 281 n. 1; cf. Cent. Bank of Denver v. First Interstate Bank of Denver, 511 U.S. 164, 173 (1993) (refusing to allow private individuals to sue under an SEC rule for "conduct not prohibited by the text of the statute"). Indeed, in writing for the Court, Justice Scalia was prevented from dismissing as invalid the disparate impact regulations because of past precedent and the parties' stipulations, but he recognized them as applications of section 602 , not section 601. See Sandoval, 532 U.S. at 281. It has been suggested that the Sandoval majority "hint[ed]" that the regulations are themselves invalid. Note, After Sandoval: Judicial Challenges and Administrative Possibilities in Title VI Enforcement, 116 HARV. L. REV. 1774, 1775 (2003). 
between the disparate impact regulation at issue in Sandoval and the regulation that it was considering. It quoted Sandoval's assertion that "it is ... meaningless to talk about a separate cause of action to enforce the regulations apart from the statute. A Congress that intends the statute to be enforced through a private cause of action intends the authoritative interpretation of the statute to be so enforced as well." 32 The critical question the Fourth Circuit then confronted was whether the regulation's prohibition on retaliation was part of the authoritative interpretation of Title VI. Examining a series of cases in which courts had held that similar civil rights statutes included private rights of action to enforce retaliation prohibitions, the Fourth Circuit concluded that the agency "quite reasonably could construe $\S 601$ to forbid purposeful retaliation based upon opposition to practices made unlawful by $\S 601 ., 33$ The Fourth Circuit considered itself bound to defer to this interpretation under Chevron and found a private right of action to enforce the regulation.

III

Ensuring that agencies have the power to create private rights of action through expansive interpretations of statutory law will contribute significantly to the effective enforcement of federal law. ${ }^{34}$ Even if there are few areas in which the courts currently recognize implied private rights of action, the ability of agencies to expand upon statutorily created private rights of action can also be important in those instances when Congress

32. Sandoval, 532 U.S. at 284 , quoted in Peters, 327 F.3d at 315.

33. Peters, 327 F.3d at 318; see also Chandamuri v. Georgetown Univ., 274 F. Supp. 2d 71, 81-83 (D.D.C. 2003). The Chandamuri court ultimately agreed with the Fourth Circuit, but did not base its reasoning on the regulations under section 601 (or 602). Instead, it argued that Supreme Court precedent had held retaliation to be intentional discrimination, and therefore determined that a retaliation claim fell under section 601 without examining the regulations. Chandamuri, 274 F. Supp. 2d at 83 (citing Perry v. Sindermann, 408 U.S. 593 (1972); and Sullivan v. Little Hunting Park, 396 U.S. 229 (1969)). This exercise in statutory interpretation is one possible approach to the narrow issue of the Jackson-Peters circuit split. However, by focusing on the ability of agencies to define the scope of the statutes that they are entrusted to enforce, this Comment's approach provides a more robust and general protection of private rights of action than does the Chandamuri court's focus on prior anti-retaliation decisions.

34. That limitations on the ability to bring private rights of action may limit the effectiveness of antidiscrimination statutes is indicated by the voluminous literature that appeared in the aftermath of Sandoval. Many commentators have attempted to identify means of ensuring continued enforcement of the disparate impact regulations promulgated under Title VI and Title IX despite the Sandoval ruling. See, e.g., Jonathan M.H. Short, "Something of a Sport": The Effect of Sandoval on Title IX Disparate Impact Discrimination Suits, 9 WM. \& MARY J. WOMEN \& L. 119, 137-42 (2002) (arguing that individuals may be able to enforce the regulations by suing under 42 U.S.C. $\S 1983$ ); Note, supra note 31 , at $1789-96$ (discussing ways to improve agency enforcement of Title VI post-Sandoval); Derek Black, Comment, Picking Up the Pieces After Alexander v. Sandoval: Resurrecting a Private Cause of Action for Disparate Impact, 81 N.C. L. REV. 356, 376-90 (2002) (arguing that individuals may be able to enforce Title VI under a theory of "deliberate indifference" or by proving intent to discriminate). 
explicitly creates a private right of action. Congress, after all, will often be unable to determine in advance how best to enforce the federal rights that it creates, ${ }^{35}$ and agencies, the entities authorized to enforce the law, will be in the best position to determine when private suits-and what kinds of private suits-will be a useful supplement to government enforcement. ${ }^{36}$

Despite the importance of agency power to create private rights of action, Justice Scalia wrote dismissively of the role federal agencies can play in creating private rights of action in Sandoval, describing them as mere apprentices. ${ }^{37}$ Yet the Fourth Circuit's decision reveals that agencies can play a significant role in defining private rights of action. Even if only Congress may create private rights of action out of nothing, federal agencies' ability to define and interpret the language in those statutes effectively gives agencies the power to create private rights of action wherever that initial statutory grant of power exists. ${ }^{38}$ After all, once Congress enacts a statutory provision prohibiting, for example, intentional discrimination, it is up to the federal agencies to define what intentional discrimination does and does not encompass. In so doing, agencies may provide any definition that is reasonable under the language of the statute. ${ }^{39}$

While agency interpretations of statutory language should receive deference under Chevron, ${ }^{40}$ that deference will not result in a private right

35. See, e.g., Mistretta v. United States, 488 U.S. 361, 415 (1989) (Scalia, J., dissenting) (noting "that no statute can be entirely precise, and that some judgments, even some judgments involving policy considerations, must be left to the officers executing the law and to the judges applying it").

36. See, e.g., Richard J. Pierce, Jr., The Role of the Judiciary in Implementing an Agency Theory of Government, 64 N.Y.U. L. REV. 1239, 1251 (1989) (arguing that where Congress does not legislate, the courts should defer to the Executive because of its expertise and greater political accountability).

37. Sandoval, 532 U.S. at 291.

38. The courts have consistently recognized an implied private right of action under section 10(b) of the Securities Exchange Act of 1934 and Rule 10b-5 promulgated thereunder. See Herman \& MacLean v. Huddleston, 459 U.S. 375, 380 (1983) ("The existence of this implied remedy [under section 10(b) of the 1934 Act and Rule 10b-5] is simply beyond peradventure."). This private right of action derives from judicial decision, see Kardon v. Nat'l Gypsum Co., 69 F. Supp. 512 (E.D. Pa. 1946), and not from agency rulemaking. But one commentator has suggested that the SEC can, if it chooses, use its power under Chevron to "disimply" this right. See Joseph A. Grundfest, Disimplying Private Rights of Action Under the Federal Securities Laws: The Commission's Authority, 107 HARV. L. REV. 963, 983 (1994). This suggests that, under Chevron, agencies have power to define the scope of private rights of action, and can use that power to restrict or expand those private rights, depending on the agency's own enforcement philosophy. If the SEC can decide to restrict broad private $10 \mathrm{~b}-5$ actions in connection with its enforcement of the Securities Exchange Act, the agencies charged with enforcing the civil rights laws should have similar freedom in deciding whether to expand private rights of action to aid in enforcement of their statutory mandates.

39. Chevron U.S.A. Inc. v. Natural Res. Def. Council, Inc., 467 U.S. 837, 842-43 (1984).

40. Not all agency actions, however, receive Chevron deference. See, e.g., United States v. Mead Corp., 533 U.S. 218 (2001) (denying Chevron deference to a tariff ruling adopted without rulemaking or adjudicative processes). Therefore, agencies seeking to establish a private right of action should use procedures that will trigger the application of Chevron deference when they are adopting relevant regulations. 
of action unless the agency interpretation is of a provision for which a private right of action already exists-either because Congress has explicitly provided for one or the courts have recognized an implied one. ${ }^{41}$ Therefore, when agencies attempt to use their Chevron power to create private rights of action through regulation, they should explicitly promulgate their regulations as an interpretation of statutory language for which a private right of action already exists. Peters would have been an easier case had the Department of Education been sensitive to the distinction between "interpreting" section 601 and "effectuating its provisions" when it drafted its regulation. ${ }^{42}$ A court is far more likely to construe a regulation as an interpretation of a statute-and thus to apply Chevron deference-if that regulation is explicitly written to define the meaning of statutory language. If the regulation is framed as an interpretation of the section for which a private right of action exists, a reviewing court that does not want to recognize an implied private right of action has only two options: It can ignore Chevron, or it can hold that the interpretation is not reasonable under the statutory language.

Indeed, despite Chevron, courts have been able to interpret statutory language narrowly and thus limit agency power; ${ }^{43}$ presumably they could do the same with regard to private rights of action. But Congress retains ultimate authority to draft statutory language. To the extent that Congress uses broad language in statutes that create (or imply) private rights of action, courts should be more likely to find that Congress did not speak to the precise issue at question, and agencies should have greater discretion to interpret that language and give it meaning.

The literal language of Sandoval may prevent agencies from creating private rights of action by themselves. But the power they retain is equally significant: They can functionally create private rights of action by expanding and defining those private rights of action that Congress (or the Court) has created. Even if agencies can only play the "sorcerer's apprentice," that is a role of considerable power. Agencies can-and should-make use of it.

—Brianne J. Gorod

41. See Sandoval, 532 U.S. at 284.

42. The Department of Education, however, states that the purpose of the anti-retaliation regulation, 34 C.F.R. $\$ 100.7$ (2003), is "to effectuate the provisions of Title VI," 34 C.F.R. $\S 100.1$. The extent to which an agency's own description of a regulation should influence a court's determination of whether that regulation merits Chevron deference is an important question, but one that is beyond the scope of this Comment.

43. Sandoval, 532 U.S. at 291 ; see also, e.g., MCI Telecomms. Corp. v. AT\&T Co., 512 U.S. 218,225 (1994) (construing a statute so narrowly as to withhold Chevron deference from an agency interpretation); Michael P. Healy, Spurious Interpretation Redux: Mead and the Shrinking Domain of Statutory Ambiguity, 54 ADMIN. L. REV. 673, 677 (2002) (arguing that the Court narrowed the scope of Chevron's application in Mead by imputing a particular legislative intent to Congress). 